\title{
TV/Series
}

$2 \mid 2012$

Les séries télévisées dans le monde : Échanges, déplacements et transpositions

\section{Representations of Power Shifts Between Great Britain and India in The Jewel in the Crown (ITV, 1984)}

Florence Cabaret

\section{CpenEdition}

\section{Journals}

Electronic version

URL: http://journals.openedition.org/tvseries/1403

DOI: 10.4000/tvseries.1403

ISSN: 2266-0909

Publisher

GRIC - Groupe de recherche Identités et Cultures

Electronic reference

Florence Cabaret, «Representations of Power Shifts Between Great Britain and India in The Jewel in the Crown (ITV, 1984) », TV/Series [Online], 2 | 2012, Online since 01 November 2012, connection on 05 May 2019. URL : http://journals.openedition.org/tvseries/1403; DOI : 10.4000/tvseries.1403

\section{(c) $($ ) $(3)$}

TV/Series est mis à disposition selon les termes de la licence Creative Commons Attribution - Pas d'Utilisation Commerciale - Pas de Modification 4.0 International. 


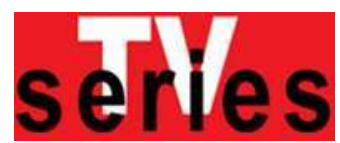

\section{Representations of Power Shifts Between Great Britain and India in The Jewel in the Crown (ITV, 1984)

Focusing on the last years of the British presence in India, this 14-episode TV serial is itself the embodiment of a first form of transfer since it is the adaptation of Paul Scott's $R a j$ Quartet, i.e. four English novels published between 1966 and 1975 telling the stories of British and Indian characters living through the last days of the Raj. Yet this paper chooses to study how this shift of power between Great Britain and emerging India is staged in a serial which is now regarded as one of the best examples of the 1980s "heritage films", in which the necessary departure of the British from India is constantly backgrounded by a nostalgic view of the British colonial enterprise. However, since The Jewel in the Crown is also described as one of the most critical representations of the presence of Great Britain in India in the 1940 s, I will also focus on the ways the serial refers to Great Britain as a privileged vantage point but also as a locus of ambivalent attitudes, particularly so as it is seen by characters living in India but appearing on television screens at a moment when British television was trying to represent the British colonial past through various kinds of programs (documentaries, fiction, serials). Several key examples are discussed along those lines: the role of the opening and end credits, the use of excerpts from British newsreels in a work of fiction, the predominance of the British gaze and the way it is visually staged in the shots, some disturbing visual intrusions and conflagrations of unexpected shots. It thus leads me to show that if the year 1947 was generally constructed as a moment of reasonable "transfer of power" from Great Britain to India, such a TV serial unsettles some of the assumptions underlying the historiographical myth which depicted India's independence as "a gentleman's agreement".

$\mathrm{F}$ ocusing on the last years of the British presence in India, the 14episode serial The Jewel in the Crown (ITV, 9 January 1984-3 April 1984) is itself the embodiment of a first form of transfer since it is the adaptation of Paul Scott's Raj Quartet, consisting of four English novels published between 1966 and 1975 and telling the stories of British and Indian characters living through the last days of the Raj. The TV adaptation is faithful to Scott's tetralogy ${ }^{1}$ in so far as the two works are quite exclusively located in India, between 1942 and 1947, i.e. between the Japanese intervention in Burma and the independence of India and Pakistan. So the predominant location and historical focal point of the serial is definitely India, and more generally Asia, with constant references to the war against Japan. Such a shift of focus from the Eurocentric treatment of World War II could first be read as a form of provincialization of Europe, which is not the main setting of the action and which is hardly depicted as the place where "world events" took place, as was still often the case when dealing with the 1940 s at the turn of the 1980s. Yet, we should not overlook the fact that the opening and closing landmarks of the serial point to the two historical

${ }^{1}$ My reference to the serial's faithfulness to the novel is actually a way to say that I am aware that authorial differences exist between the two works and that it would be the object of another article to investigate the variations of viewpoints on the issue of power shifts between Great Britain and India in the literary version and in its filmic adaptation. 
threats that were power transfer and loss of India by Britain given Japan's imperial appetite during the war and the growing demands of Indian nationalists for independence. So the favoured viewpoint is clearly that of Great Britain, which dreaded losing one of the main parts of its empire. This is illustrated by the choice of protagonists in the serial, who are mainly British and stand as the main focalisers (actors and witnesses) of the gradual retreat of the British from India and the ways they experienced this demise. This may explain why the serial has often been described as either embodying "Raj revival films" or "heritage films", two cinema trends which are said to offer the viewer stories expatiating on the grandeur of Great Britain while glossing over the harshness of the times and ignoring the viewpoints of the colonised ${ }^{2}$. This sounds like a rather fair presentation of The Jewel in the Crown, which tries to illustrate the complexity of the links between the Jewel/India and the Crown/Great Britain, but which turns out to favour the crown over the jewel. Some critics have thus pointed out that the serial seemingly transgresses certain boundaries (having to do in particular with inter-racial relations and miscegenation, as well as with hetero-normativity and patriarchy), but most of the time critics also underline the failure of those attempts at transgression which, in the end, only maintain limits and assert the impossibility of exchanges and crossovers ${ }^{3}$.

In my approach, I would like to show how the representation of space and places in particular could lead us to side with such a critical approach of the serial, but I will also discuss a selection of moments when ambivalence is at work, putting to the test the assumption according to which The Jewel in the Crown only projects a nostalgic and melancholy gaze over a lost empire.

\footnotetext{
${ }^{2}$ For one of the first denunciations of "Raj revival film", see Salman Rushdie, "Outside the Whale", Granta, No. 11, 1984, p. 125-138. For further information about "heritage cinema", see Andrew Higson, English Heritage, English Cinema. Costume Drama Since 1980, Oxford, Oxford University Press, 2003

3 Indeed, those critics tend to emphasize the regressive and biased gaze such films cast on Great Britain's past so that contemporary issues (some of them having a direct link with immigration from the former colonies) are surreptitiously evacuated from the films. In a presentation of the mini-series on the website of the Museum of Broadcast presentation of the mini-series on the website of the Museum of Broadcast
Communications, Peter McLuskie writes: "These fictions were produced during, and indeed reflected, a moment of crisis and change in British life: mass unemployment, the arrival of new social and class configurations tied to emerging political and economic trends all conspired to destabilise and recast notions of national and cultural identity in the early 1980 s. While often critical of Britain's past, these fictions nevertheless permitted a nostalgic gaze back to a golden age, presenting a vision of Empire as something great and glorious. These fictions seemed to offer reassurance to the British public, as cultural fetish objects they helped negotiate and manage a moment of social and political upheaval."

www.museum.tv/eotvsection.php?entrycode=jewelinthe, consulted August 2012.
} 


\section{Permanence in spite of transience, or staying even though leaving}

One of the prominent features of the first four episodes is a developing tension between the characters' growing awareness that they are bound to leave India sooner or later and their - both conscious and unconscious - reluctance to accept such a prospect. The series definitely plays with this idea of permanence (of the British presence in India) countering the looming certainty of a change to come, in an attempt to visually preserve, in fiction, the last days of the British Empire, which is quite typical of "heritage films".

Thus, in spite of the evolution of the story towards the British departure from India, and in spite of our knowledge of this turningpoint in the history of both countries, each episode appears to maintain the image of Great Britain as a ruler in India. Resorting to a familiar introductory device for TV series and serials, i.e. the recurrence of the same opening credits, The Jewel in the Crown seems to favour a pervasive sense of stability trying to compete with the assurance that the end of the British Raj is at hand. The reiteration of the opening credits, combined with the musical leitmotiv of the soundtrack, creates a form of hypnotic effect and suggests a visual persistence of the pomp of the British Raj, showing several ceremonial, official moments where groups of Indian men intervene as marching soldiers or rewarded officers, and constantly ending with the clichéd scene of the tiger hunting expedition, with white people comfortably seated on elephants while a long column of Indian luggage carriers cross a river on foot. The fact that Indian people may only play background, subordinate roles is also enhanced by the nature of the images chosen for the credits since they are documentary images whose seeming truthfulness may appear to validate the reality of the Indians' subordinate status from the outset of the serial (see Plates 1 and 2).

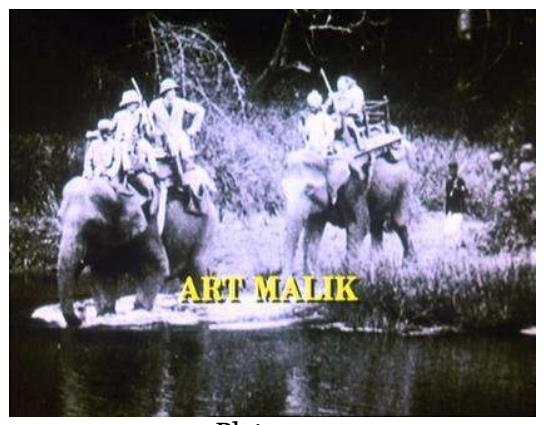

Plate 1 


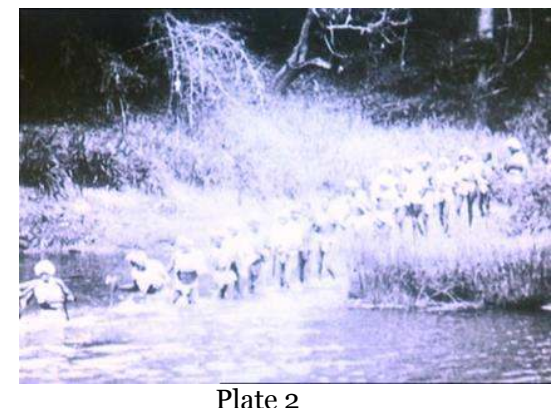

The opening shots of the first four episodes are in keeping with the serial's tendency to locate the viewer in an India which seems eternal and remains impervious to change thanks to the recurrent choice of peaceful rural landscapes which would fittingly embody an Indian form of Arcadia. Episodes 1 and 2 start with similar shots of the immobile Indian countryside at night whereas movement and change are foretold by the two titles ("Crossing the river" and "The Bibighar Gardens"), which hint at the crossing of a river from the Indian district to the British district, or at the discovery of a secluded ancient Indian cemetery where Indian bodies and English bodies will meet in both amorous and savage embraces ${ }^{4}$. However, in episodes 3,4 and 6 , the titles which are superimposed on the opening shots slightly undermine the reassuring aspect of the landscapes ("Questions of loyalty", "Incidents at a wedding" and "Ordeal by fire"). Including echoing nouns and adjectives such as "regimental" and "regiment", the titles of episodes 5 and 7 ("The Regimental silver" and "Daughters of the Regiment”) remind us of the British military presence in India, which is not confined to official and decorous ceremonies. What is more, after episode 8, the opening shots become more explicit and ominous, focusing on the well-known motif of "the mad woman in the attic 5 ". By hinting at a narrowing of perspective and mental collapse of those British people living in India (especially women), they also depict India as a trap the British had to flee from if they did not want to end up mad like Barbara Batchelor (a retired missionary teacher) or Susan Layton (a young English woman who becomes a widow while being pregnant with her first child). As for the flags which appear at the opening of

4 The promise will actually be fulfilled by the newly-arrived British Indian Hari Kumar, when he meets British Daphne Manners - who has also just arrived in India - one evening at the Bibighar Gardens, just before she is raped by Indian assailants while Hari Kumar is beaten up and gagged by these very same Indian muggers.

5 A phrase recycling a famous British classic, Jane Eyre, which also inspired Sandra Gilbert and Susan Gubar the title of a book they dedicated to Victorian female writers and heroines: The Madwoman in the Attic: The Woman Writer and the Nineteenth-Century Literary Imagination (Yale University, 1979). 
episodes 12 and 13, they also re-inscribe the official presence of the British in India, even though they are shown in fairly inauspicious scenes: the flag of episode 12 can indeed be read as the frail defence of an isolated British stronghold while the flag of episode 13 literally covers the coffins of the Raj's most active agents and supporters. Finally, episode 14 leaves the viewer in little doubt about the ultimate demise of the British, even though the dark fire smoke rising from the luminous town of Mirat is commented on by Count Bronowski and Guy Perron as a prefiguration of the coming riots between Indians more than as a sign of conflict between the British and the Indians.

Now, when we compare the opening credits with the end credits of all the episodes, we realise that the end credits tend to be more dramatic and to refer more explicitly to entrapment, disquieting atmospheres and destruction. Fire is a particularly effective and recurring symbol of an impending threat. Episode 12 ends with the burning of the picture of Hari Kumar, pointing to the failure of the British to accept a man who obviously felt more British than Indian, not to mention the racist prejudice that led the British to condemn a man who is wrongly accused of rape ${ }^{6}$. The last episode freezes on the burning of The Jewel in the Crown, a painting of Queen Victoria receiving a jewel from an Indian prince. Throughout the episodes, the painting has been passed on from one character to another, triggering conversations about the dream Great Britain had about India - a dream of cooperation and civilisation, which has been crushed by the 1947 transfer of power according to different British and Indian characters. In these final two still shots, the series illustrates its own ambivalence as to its perception of the Raj: either as a dysfunctional system whose collapse was self-planned or as the regretted embodiment of high hopes ruined by misunderstandings.

The DVD presentation of the series reduplicates and highlights such an oscillation. Playing on the viewer's foreknowledge of India and Great Britain's joint history, the DVD box and menu foreground the motif of a burning map of (British) India, recalling the tragic perception of the loss of the Indian continent. But, simultaneously, they bring to the fore the last champions of the Raj by showcasing five characters in picture frames so that they are staged as those who will remain in our memories in spite of the actual crumbling of the British Empire: the impossible lovers, in separate picture frames (Daphne Manners and Hari Kumar), the caring aunt, who may act as a double of a benevolent British queen (Lady Manners) and the lovers who may end up reunited, even after 1947 (Susan Leyton and Guy Perron). All of them appear as protecting and positive figures in the serial, even though they are powerless witnesses, condemned to watch and tell

${ }^{6}$ Hari is accused of raping Daphne after the couple is attacked by unknown men in the Bibighar Gardens (see note 4). 
about the gradual retreat of the British from India. This dimension of the characters as bearers of testimony but also as observers more than as actors is supplemented by several editing techniques, among which the use of documentary images.

\section{The history of India seen through the prism of Great Britain's World War II}

To provide historical landmarks and credentials to the viewer, the serial regularly resorts to newsreel images shot in the 1940s. But again, these images do not exactly refer to what happened in India, especially with the rising tensions around the question of independence. On the contrary, these Indian events are marginalized by the dominating concerns of the British, i.e. the Japanese armies threatening to invade India or to help Indian dissidents raise an army of liberation. So, if WWII in Europe is almost absent from the news clips used by the serial, Indian history proper is clearly not a central ingredient in the narrative, contrary to the advances and retreats of the British and Indian troops in Burma in particular. The superiority that the serial grants to the British viewpoint over the Indian viewpoint is again illustrated in a good number of examples. One may think of the exclamation "Stand fast India!", which accompanies newsreel images of troops' parades and movements in episode 1: it sounds both like a plea and an order, whose final target is less India in itself than the integrity of the British empire in South-East Asia. The dread of losing India is also conveyed by British propaganda pictures, which show the combined efforts of the British and Asian troops to hold at bay the spectre of Indian treason and the desire for emancipation from the British crown 7 . When, on a few occasions (which makes them all the more noticeable), events in the European theatre of operations are mentioned, they provide an indirect commentary on the situation in India from a British vantage point. Thus, in episode 6, D-Day in Normandy is read as a promise of victory in Asia against the Forces of the Axis, i.e. of Great Britain vs. Japan. But the filming of an Indian regiment behind barbed wires when they have just participated in the liberation of a German prisoners' camp (as the caption "Free!" indicates) creates a jarring effect when one considers that Indian people had not yet been emancipated from British tutelage.

As for the shot of the Hiroshima explosion, which is inserted with no specific explanation in episode 11, it also refers to another (symbolically) cataclysmic event which was to take place two years later in India. The insertion and integration of those "real" images

\footnotetext{
7 For further information about the complexity of political interests in India during the Second World War, see Auriol Weigold, Churchill, Roosevelt and India: Propaganda during World War Two, London, Routledge, 2008.
} 
meant to be shown in Great Britain so as to apprise "people at home" of what happened on far-away fronts in the 1940s draws attention to the choice of a viewpoint informed by the necessity to protect India as part and parcel of the British mother country, whose power in Europe mainly relied on its presence in Asia. Still, in the 1980s, when the series was first broadcast, the emphasis laid on the unity between Indian and British soldiers during World War II echoed British home worries, with race riots taking place in several cities at the start of the decade - an outcome of the Commonwealth Immigration Laws of the 1960s, of the flagging labour market, and of the emergence of anti-immigration campaigns led by the National Front and the New Right during the 1970s. Although it was aired long before the 2005 London bombings, the serial is haunted by the disruptive figure of the "enemy within" and endeavours to trace model references of Indian courage and faithfulness, but also of Indo-British friendship, political alliances and love affairs. If this helped build a more balanced representation of the British Raj for 1980 os TV spectators, it nonetheless consolidated the serial's tendency to promote a domestic viewpoint over an Indianoriented viewpoint.

\section{A disquieting feeling of English familiarity}

Apart from the two types of examples we have just dealt with (credits and newsreel images), we cannot but be struck by the visual domination of British viewpoints over Indian viewpoints that fundamentally characterizes the serial. We may even go as far as to suggest that, even though the whole serial takes place in India, the British viewer is hardly ever unsettled nor defamilarized by this change of location as India undergoes a constant process of visual domestication - whether it be through the perception of Indian characters by English characters, or the fact that most scenes are shot in indoor locations, or even the prevalence of the English gaze over Indian landscapes.

Nearly all scenes revolve around white British characters, so that the scenes showing prominent Indian characters are in a minority. They can roughly be divided into two categories: gap-filling scenes or political scenes. Typical examples of the first group are street scenes, which are manifestly not shot with professional actors, while the most representative examples of the second group of scenes are conversations between fictitious Indian men of influence (episodes 4, 8 and 12). If these political scenes may appear to make up for the overall tendency to underestimate the role played by Indian people both in the downfall of the Raj and in the serial, their narrative peculiarity in the general economy of the episodes testifies once more to their relative marginalization in/by the serial. Three Indian characters stand out as regular protagonists in those scenes: Ahmed Kasim (the personal 
secretary of a Russian count), his brother Sayed Kasim (originally a King's Commissioned Officer), and their father Mohammad Ali Kasim, a prominent Indian politician whose commitment to the cause of Ghandi earns him some time in prison as well as creating tension with his more radical son, Sayed, who joined the INA (Indian National Army). Even though they are family to each other, this dimension of their characters is ignored by the narrative, which contributes to keeping them apart from the main group of white characters. Indeed, the three men appear to have no personal life that would give them "proper substance" in a serial which relies heavily on the twists and turns of the characters' lives (comings and goings, marriages, deaths and accidents, but also enquiries, rumours, secrets involving private behaviour most of the time). So, paradoxically, their confinement to a political role in the story leaves them on the margins of the serial, however effective their actions may prove in the British downfall, which is undeniably the backbone of the whole narrative.

The other domesticating pattern in the serial relies on the location of a vast majority of scenes, which are shot indoors, in very British interiors that are propitious to intimate talks and revelations, but also to social conversations at clubs and parties. Most of the time, these shots are crammed with paintings, engravings and pictures representing British landscapes, or monarchs, or other figures of authority, not to mention the objects, pieces of furniture, articles of clothing and decoration conjuring up images of British rooms as you expect to find them in Great Britain. In addition, a certain number of still shots reinforce the viewer's sense of an immobile Great Britain in India, holding onto itself and resisting change as much as possible (still shots of clocks on mantelpieces, of bedside tables, of desks, etc.). We may sometimes even have the impression that we are watching a reconstitution of Great Britain abroad, but of a Great Britain that would be closer to a Jane Austen adaptation for the television (see the graveyard scene with Barbara Batchelor in episode 7, announcing the type of shots in the 1987 BBC adaptation of Northanger Abbey ${ }^{8}$ ). Such a visual proximity with one of the paragons of Englishness in literature, not to mention the way TV adaptations have greatly contributed to construct Jane Austen's mansions and cottages as the epitome of English domesticity at the turn of the $19^{\text {th }}$ century, reinforces the impression that time has stopped and that the progress of history is potentially hindered by the pervasive immobility of indoor scenes, where standing and remaining seated prevail.

Although a good number of scenes are shot outdoors and display movements and actions, we cannot help noticing the recurrent emphasis on British characters looking at Indian landscapes, which are almost always framed by the words of a British character or by a British

${ }^{8}$ This film was directed by Giles Foster and written by Maggie Wadey. 
gaze. What is striking is that white people commenting on Indian places frequently superimpose an English reference, pointing to the well-known pattern of appropriation of the other through one's closest and innermost representations. Such is the case in episode 2, when everybody is awaiting the monsoon and Daphne Manners imagines that soon "everything will be green and fresh like England". Or when she talks with Hari Kumar, who tells her that he has never been to the Bibighar Gardens, to which she retorts: "I suppose that's like living in London and never see the Tower". The irony of the second instance lies in the fact that Hari Kumar, even though labelled as an "Indian" character, is actually more familiar with London than he is with Mayapore and its ancient monuments.

Now, when we try and organize a classification of outdoor scenes in the serial, we realize that most of them are moments of transition, both in the narrative and in the narration. If some scenes stage arrivals and departures, along with their necessary gatherings and partings, many others are shot from a means of transport which conspicuously appears in the shot, whether it be a rickshaw or a cart (episode 1), a bike, or a boat (episode 3), a train or a plane (at the end of the last episode). It all gives a sense that the viewer is going through a farewell visit to a country which would thus be enshrined in window cases (like the regimental silver of episode 5). Comfortably seated in front of their TV screens, 1980 s viewers embarked on a guided tour of a lost Empire, just as Merrick shows the most renowned places of the town where he welcomes Sarah Clayton in episode 4, or like Sarah Clayton and Guy Perron, who pay a visit to the abandoned guesthouse (episode 12). Transport can also be a mental movement, as in the sleep scene of episode 7 , in which the Indian landscape gradually emerges from Sarah Clayton's dream in a typical cross-fade scene, metanarratively underlining the constructed nature of the Indian landscape in the serial. Such a form of melancholy and valediction also materializes in those shots where the observer's back partly conceals or borders what he/she beholds - a visual device which recalls the aesthetics of the picturesque and sublime of $18^{\text {th }}$-century British travellers and romantic painters during the rise of the British Empire, for whom the subjectivity of the beholder stood at the core of their work.

But, however familiar these images may look, the serial surreptitiously introduces disturbances in what is not just a smooth rehearsing of well-known, pleasurable views of India and British people in India. Thus, Daphne Manners and Hari Kumar sometimes manage to escape the strict and polished indoor scenes for a few moments in the surrounding garden of Aunt Lili's house, which prefigures the moment when they unexpectedly meet in the Bibighar Gardens at night. If the motif of the two star-crossed lovers finding respite far from the society of inquisitive acquaintances is common 
enough in fiction, the rain scene which will lead to their sexual embrace may be read as a British stiff-upper-lip version of the wet sari scenes frequently inserted into Bollywood films. This intertextual allusion to a much more "Indian" staging of a similar scene somewhat displaces the scene towards another kind of cinematic universe and suggests the possibility of a re-orient-ation of our gaze on the serial. Other scenes question more explicitly the limitations of the British characters' (and spectators'?) views of India. I am thinking in particular of those scenes when Daphne Manners clumsily fumbles with her spectacles, complains about their inadequacy or tries to do without them so as to form a better picture of the Indian landscape. The most ludicrous of these scenes is undoubtedly the one when she appears not to see the middle part of the body of a standing Hari Kumar as she is sitting in front of him in the Bibighar Gardens (episode 2). More tragically, the scene when Ronald Merrick, the superintendent of police, confronts the naked body of the same Hari Kumar in the torture room of the prison points to Merrick's blindness to his repressed attraction for men (episode 3). But the way the scene is shot is quite transparent for the viewer, who is thus given another hint that more complex versions of India have long been kept underground and are partly disclosed by the serial, as evidenced by the fortuitous discovery of Ronald Merrick's secret meetings with a young Indian boy in episode 14 .

Other disturbances are triggered by the unusual gathering of signs or people in otherwise familiar circumstances, which again hints at another reality below the surface. One shot of Aunt Lili's hall (episode 1) thus features a miniature Big Ben Tower, which looks as if it were made out of the white material traditionally used for miniature representations of the Taj Mahal (hence, a first disturbance). What is more, the position of the Big Ben Tower in the camera frame gives the impression that it is threatened by a stuffed tiger which stands on the right-hand side of the frame, seemingly roaring. The shot is composed as a mock figuration (the Tower is miniature, the tiger is stuffed) of an underlying fear that is hidden in the setting (see Plate 3). 


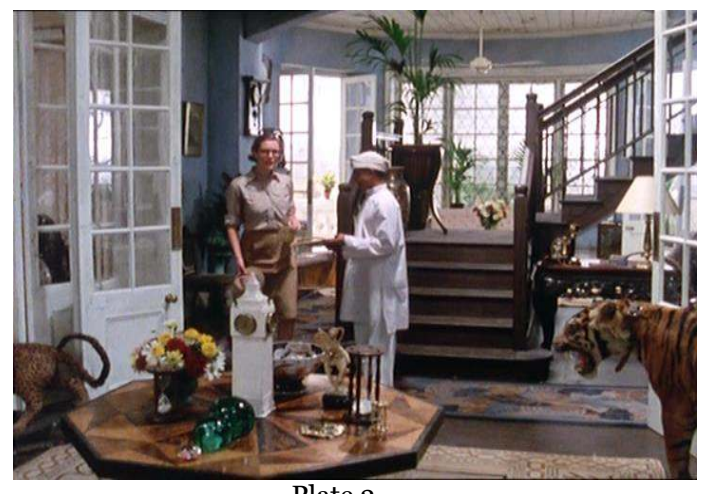

Plate 3

Later, in episode 10, an Indian party where Indian transvestites dressed up like European ladies try to seduce British soldiers serves as a foil to previous scenes which displayed straight and official British authority over the Indians (see the opening credits). Yet, as early as episode 1, we are introduced to a "War Week Exhibition" where the apparent British control and power over the Indians is undermined by the simultaneous presence of Hari Kumar and of a British banner claiming "V for Victory" in the same shot. Whose victory will it be in the end? This one shot may suggest alternative answers as the intrusion of an Indian face in the camera frame blurs the meaning of the motto and redirects it towards Indian speakers, working for another kind of victory in the wings of Western history (i.e. the victory of Indian nationalists over British colonizers, in particular). So the viewer has to find his/her own way between the interspersed debunking shots and the prevailing familiar exotic images which recall 1980s TV documentaries ${ }^{9}$ and pictures showing sometimes excessively decorated, museum-like houses arranged by Britishers who wanted to be reminded of home and who thought they had thus transferred a part of Great Britain to India. Indeed, if the serial has been identified by several commentators as "the acme of British quality ${ }^{10}$ " and as a way to support a regretful view of the British Empire, one must acknowledge that it does not strictly evade all tricky questions about the Empire. Some critics have rightly argued that the British faults pointed out by the serial tend to fall back on individual responsibility more than on

9 One may think of the famous BBC series of travel documentaries known as Great Railway Journeys, and in particular episode 3 of the first season entitled Deccan, which was broadcast on November $13^{\text {th }}, 1980$, and was dedicated to a train trip from Bombay to Cochin.

${ }^{10}$ Charlotte Brunsdon, Screen Tastes: Soap Opera to Satellite Dishes, London, Routledge, 1997, p. 142. See also George W. Brandt, British Television Drama in the 1980s, Cambridge, Cambridge University Press, 1993, p. 196-213. 
collective responsibility. A case in point would be the caricatured character of Ronald Merrick, who is too blatant a scapegoat, easily sacrificed and dismissed at the end of the narrative itself ${ }^{11}$. The same can be said about women, who are presented as "figures of conscience, cause, impotence" since they "criticize the manners of empire but not the enterprise itself"12, trigger sexual tension among Indian men and British men/women, but are powerless to change the course of events $^{13}$. Even though such conservative ambivalences were already present in Paul Scott's 1966 quartet, it appears that nearly twenty years later the serial adopts a similar stance, illustrating the embarrassment which was still caused by the question of the British Raj, especially as many of its Indian descendents had become British citizens. The shooting, the editing and the reception of the serial give us a glimpse of the way the 1980 s British society obviously conceived and perceived the serial as a form of self-commentary.

\section{Driving the point home: self-examination of Great Britain via India}

One last emblematic example of the prevalence of selfrepresentation and self-observation is to be found in two embodiments of "homecoming", both questioning the comfort, pleasure and hopes with which the notion is frequently endowed. Interestingly enough, the two "inadequate" characters of Hari Kumar and Ronald Merrick contribute to displacing the mooring point which they regard as "home", contrary to what others would consider to be their home.

${ }^{11}$ See Elena Oliete Aldea, Filmic Representations of the British Raj in the 1980s: Culture Identity, Otherness and Hybridity, Doctorate Thesis, University of Zaragoza, March 2009, p. 398 (http://zaguan.unizar.es/record/3260/files/TESIS-2009-057.pdf, consulted August 2012). As for Richard Dyer, he describes Ronald Merrick as the embodiment of Thatcherite traits (lower class, policeman, racist, anti-liberal) and explains that the obvious choice of the serial to stage him as the villain signals the anti-Thacherite dimension of the serial. Simultaneously, he also notices that the negative representation of his hidden homosexuality actually reflects the homophobia a certain number of pro-Thatcher supporters would have sided with in the 1980s. Richard Dyer, White, London, Routledge, 1997, p. 196. Such a politically-incorrect portrayal of a homosexual man as a villain may have been a way for the serial to underline how much hatred of the "other/queer" may well backfire and turn into self-hatred and self-destruction.

${ }^{12}$ See Dyer, p. 186.

${ }_{13}$ Dyer's chapter on The Jewel in the Crown uses an emblematic and recurrent female utterance as a title: "There's nothing I can do about it! Nothing!" (Dyer, p. 186). See also an interesting development in Aldea, p. 418-422, about the 1980 s backlash view of feminism as embodied by the two central female characters, Daphne Manners and Sarah Layton. Indeed, after taking the initiative in her love affair with Hari Kumar, Daphne Manners may be described as adopting a stubborn and foolish behaviour resulting in the torture of her lover, but also in her own death. On the contrary, Sarah Layton would stand as a contrapuntal character, as she has forced, loveless sex with a white man, and then has a discreet abortion and survives with no apparent harm done or taken. Again, in the conservative view of the beginning of the 1980s, "she represents no threat for the established order" (Aldea, p. 422). 
Thus, Hari Kumar, who is first introduced as Harry Cumer (i.e. through the English pronunciation of his name), states from the outset of the serial that he did not come back home when he arrived in India. To him, "home" is Great Britain, where he was raised and educated, but which he was compelled to leave on account of financial difficulties. That is why he joins the only family which is left to him, even though he has never visited his Indian aunt once in his young life and even though he does not speak a word of Hindi. As for Ronald Merrick, he is a former grammar-school boy who feels uneasy among the upper-class British people he has to socialize with as District Superintendent of Police in Mayapore. At the end of the serial, just before he is murdered, he calmly acknowledges that, contrary to most British people living in India, he will not be able to go back to Great Britain and will prefer to stay on and go to the North West frontier or to Peshawar "somewhere they don't do things by the book", where he will feel definitely more at home. The serial stands between these two declarations of unbelonging, reversing at its opening and closing the idea that for an Indian-looking man, his home is necessarily India, but also the idea that in order to be and feel English, you just have to be white. The bitter irony of it all lies in the fact that Hari Kumar is actually the first English character that is shown to the viewer, who may tend to be blinded by his skin-colour but also by his silence as he is unconscious and unable to speak when Sister Ludmila discovers him. At the other end of the serial, a few flashbacks conjure up images of Harry Cumer playing cricket with friends when he was a student at Chillingborough, a fictional elite private school. Symmetrically, in another moment of flashback, Ronald Merrick is disclosed as a man who enjoyed wearing Pathan suits, especially when he entertained young Indian men in his apartments at night. While recycling the hackneyed images of the foreign man as a good sportsman and of the white man gone native who cannot come back home and dies because of his transgression (in the fashion of Kurtz in Joseph Conrad's Heart of Darkness), The Jewel in the Crown undeniably echoes 1980 s political questions such as what it meant to be British in Great Britain in those days. These issues had also started to be culturally addressed in British TV shows of the $1970 \mathbf{S}^{14}$, as so-called second-generation "immigrants" started to become a more visible part of British society. In the wake of the early 1980 s race riots, more active media policies were officially undertaken by cultural institutions to bring racial issues to the fore on TV screens and theatre stages ${ }^{15}$. More individual

14 See Amandine Ducray, Les Sitcoms ethniques à la télévision britannique de 1972 à nos jours, Paris, L'Harmattan, 2009. See also Amandine Ducray's article in the present issue of TV/Series.

${ }^{15}$ Sarita Malik depicts the period as characterised by "institutional and cultural attempts to harness good racial relations". She recalls the influence of US multiculturalism and of the growing "Race Relations Industry" in the British debates of the time and she refers to 
initiatives were also of help. Originally a playwright, Hanif Kureishi raised the question of the representation of the Asian community on the British fringe stage with such plays as Borderline (1981), Birds of Passage (1982) and Outskirts (1983). His going into cinema in 1985 with My Beautiful Laundrette served the same purpose: a film directed by Stephen Frears and shot one year after The Jewel in the Crown, it was originally planned as a TV program which, to both Kureishi and Frears, seemed to be a better way to reach a wider audience than cinema $^{16}$. Then, in 1993, Kureishi's decision to turn his first novel, The Buddha of Suburbia (1990) into a BBC mini-series was part of a similar desire to have white British people realize that Asian people were also British people living, laughing and crying next door, in London and its suburbs, and not only in a fetishised Raj as elicited by such successful filmic adaptations as Heat and Dust (directed by James Ivory in 1983) or A Passage to India (directed by David Lean in $1984)^{17}$.

The Jewel in the Crown stands at a crossroads, where others were ready to make more radical choices than the serial's ambivalent attempt at changing viewpoints. Just like Daphne Manners, it desperately holds on to its pair of spectacles even though it tries hard to get rid of them. But the abundance of visible frames within the shots, the frequent presence of blinds and shutters protecting characters from the heat and sun, but also preventing them from properly looking at the surrounding world (which is sometimes reduced to a regularly scrutinized map on the wall) attract our attention to the uneasiness of true vision. As nearly all the characters are shown gazing at the landscape at one stage or another in the serial, they appear as doubles of the spectator, warning us against a similar fascination with the beauty and beautification of the Indian landscape - even though it may be one of the most seductive ploys of the serial. Visual props orienting the viewer's perspective or blocking his/her view find a relevant

“initiatives such as the Arts Council's Ethnic Minority Action Plan which emerged out of the post-1980s riot context" ; she also shows how it led the British cultural world to launch into more active anti-racist agendas (Sarita Malik, Representing Black Britain: A History of Black and Asian Images on British Television, with a foreword by Stuart Hall, London, Sage Publications, 2002, p. 18-19).

${ }_{16}$ This is also the way Kureishi accounts for his decision to shift from play-writing to television script-writing: "The great advantage of TV drama was the people who watched it; difficult, challenging things could be said about contemporary life. The theatre, despite the efforts of touring companies and so on, has failed to get its ideas beyond a small enthusiastic audience." (Hanif Kureishi, "Introduction to My Beautiful Laundrette", in Dreaming and Scheming. Reflections on Writing and Politics, London, Faber and Faber, 2002, p. 124).

${ }^{17}$ Salman Rushdie also contributed to the debate in his essays about films such as Gandhi (dir. Richard Attenborough, 1983), A Passage to India (dir. David Lean, 1984), and the TV serial The Far Pavilions (HBO's first mini-series in 1984): see, for instance, Salman Rushdie, "Attenborough's Gandhi" (1983), in Imaginary Homelands. Essays and Criticisms: 1981-1991, London, Granta Books, 1991, p. 102-106. 
illustration in the attempt conducted by Daphne's aunt, Lady Manners, to disclose the truth about her niece's rape in episode 5. After the death of the young woman, Lady Manners confidentially asks for a further examination of the circumstances that led Hari Kumar to remain silent during the interrogation conducted by Ronald Merrick (even though Kumar was wrongly accused of having assaulted Daphne at the Bibighar Gardens, he actually never denied the crime). The scene when she is introduced into the prison where Hari Kumar is still locked up multiplies shots and frames showing her secretly listening to the prisoner behind blinds in a room apart. She is seen as no less trapped than Hari Kumar as she bitterly understands that her glimpse of the truth puts her in no capacity to act since raison d'état ranks higher than the fate of individuals. The serial goes as far as to admit that it was necessary to safeguard the public image of British procedures at a crucial moment of negotiations for the oncoming transfer of power between the Indians and the British. So the viewer has to make do with dramatic irony and the superior knowledge he/she has over the characters, but the characters themselves remain either unaware of the truth, or, when they know about it, superior interests prevent them from exposing that truth. Even Ahmed Kasim, during the slaughter scene taking place in the train at the end of the serial, remains silent as to the fate that awaits him although he can perfectly decipher the signs lurking in the landscape behind the train shutters. As he understands that, on the eve of the Partition, Hindu men have ambushed the train because they are coming after Muslim people and after him in particular, he leaves the compartment without a word of protest, neither on his part nor on the part of his English friends and fellowtravellers. On both sides, the illusion of India's independence as "a gentlemen's agreement" is momentarily preserved. And it is only when the train reaches the next station that the viewer fully understands that most Indian passengers have been brutally murdered by those who stopped the train to kidnap and actually murder Ahmed Kasim, as we are shown the reactions of horror of both British and Indian men and women waiting for passengers on the platform. However, the narrative of India's independence by Guy Perron in the last episode testifies to the serial's desire to give voice to a long-repressed version of the events that took place in India, and to bridge Indian and British knowledge about the tragic events that surrounded this long-awaited political emancipation. His intellectual and first-hand acquaintance with India is underlined on several occasions: he was in the intelligence service in India in the 1940s, he happens to be a historian trained in Indian history at Cambridge, he is the one going back to the place where Mohammad Ali Kasim was murdered so as to get some more information and take care of the body, and he is also the one who gradually learns about Hari Kumar's case before he eventually tries to get in touch with him. So Guy Perron emerges as a potentially clear- 
sighted protagonist who may have the ability to gather various viewpoints and may be able to confront and bring them to public knowledge through a thorough retrieval of written testimonies, rumoured stories and first-hand memories.

Finally, we could fruitfully characterize Guy Perron as a figure who enables the serial to dramatize its own role in the process of shifting boundaries and trying to unveil the Indian past, even though it fails to balance the British viewpoint on the simultaneous independence and partition of the Indian continent. Thus, the final fading of colours that is used to shoot Guy Perron's plane taking off, and which smoothly leads to the integration of black-and-white newsreel images of the $15^{\text {th }}$ of August 1947, reminds us that the British historian may be conceived as a mediator of Indian events which were no less fabricated by 1947 filmic propaganda than they are now by a work of fiction. Even if we admit that the serial manages to cast light on the construction of predominant British viewpoints in the narrative of this transfer of power, it only offers tentative alternative versions to a dominating British discourse which is not ready to give way to its Indian counterpart. Although episode 14 closes on a free Hari Kumar writing at his desk, the character who might have been the lead figure of the story (after all, he was shown as the lover of Daphne, even kissing her on the lips in a both restrained and sensuous scene at the Bibighar Gardens) and who contributes to the revelation of political and judicial manoeuvres on the British part, is nonetheless gently pushed back into the wings of history as Guy Perron's voice-over states that Hari Kumar was absent when he went to his flat. We may say that the character of Mohammad Ali Kasim undergoes a similar marginalising treatment, with some hints at a love affair with Sarah Layton and a crucial political role that is brutally shattered by Muslim activists, leading to his total disappearance from the screen when India's transfer of power is carried out - as if to visually belittle the Indian role in the process of independence. More generally, the deficient contextualisation of the Indians' independence claims (both Muslims' and Hindus') and the lack of information about the growing pressures imposed on India by the war effort tend to downplay the respective responsibilities of the various British and Indian actors in this historical achievement. We have thus shown how the emphasis laid on British observation tends to mitigate the role of the British in their own departure and in the trauma of Partition. Though we may agree to say that The Jewel in the Crown participated, albeit imperfectly, in the re-evaluation of darker versions of the victors' history, it appears that it was not able yet to follow the much more radical and new shift of viewpoint that Subaltern Studies in India had recently started to work on with the publication in 1982 of the first volume of the series of Subaltern Studies: Writings and Essays on 
South Asian History ${ }^{18}$. Still, in the wake of the Booker Prize awarded to Salman Rushdie's Midnight's Children in 1981, the serial was definitely caught in a moment of general reconsideration of India and Great Britain's past, when "writing back" and "striking back to the empire" could also be performed on the field of televisual culture.

\section{Bibliography}

ALDEA Elena Oliete, Filmic Representations of the British Raj in the 1980s: Culture Identity, Otherness and Hybridity, Doctorate Thesis, University of Zaragoza, March 2009.

(http://zaguan.unizar.es/record/3260/files/TESIS-2009-057.pdf)

BRANDT George W., British Television Drama in the 1980s, Cambridge, Cambridge University Press, 1993.

Brunsdon Charlotte, Screen Tastes: Soap Opera to Satellite Dishes, London, Routledge, 1997.

DUCRAY Amandine, Les Sitcoms ethniques à la télévision britannique de 1972 à nos jours, Paris, L'Harmattan, 2009.

DYER Richard, White, London, Routledge, 1997.

GuHA Ranajit, ed., Subaltern Studies: Writings and Essays on South Asian History, New Delhi, Oxford University Press India, 1982.

Higson Andrew, English Heritage, English Cinema. Costume Drama Since 1980, Oxford, Oxford University Press, 2003.

KUREISHI Hanif, "Introduction to My Beautiful Laundrette", in Dreaming and Scheming. Reflections on Writing and Politics, London, Faber and Faber, 2002, p. 123-126.

MALIK Sarita, Representing Black Britain: A History of Black and Asian Images on British Television, with a foreword by Stuart Hall, London, Sage Publications, 2002.

Rushdie Salman, “Outside the Whale”, Granta, No. 11, 1984, p. 125138.

\footnotetext{
${ }^{18}$ Ranajit Guha, ed., Subaltern Studies: Writings and Essays on South Asian History, New Delhi, Oxford University Press India, 1982.
} 
“Attenborough's Gandhi” (1983), in Imaginary Homelands. Essays and Criticisms: 1981-1991, London, Granta Books, 1991, p. 102106.

WEIGOLD Auriol, Churchill, Roosevelt and India: Propaganda during World War Two, London, Routledge, 2008. 